\title{
Variations of the geomagnetic field during the Holocene: Relative paleointensity and inclination record from the West Pacific (ODP Hole 1202B)
}

\author{
Carl Richter $^{\mathrm{a}, *}$, Alessandra Venuti ${ }^{\mathrm{b}}$, Kenneth L. Verosub ${ }^{\mathrm{c}}$, Kuo-Yen Wei ${ }^{\mathrm{d}}$ \\ a Department of Geology, University of Louisiana at Lafayette, P.O. Box 44530, Lafayette, LA 70504, USA \\ ${ }^{\mathrm{b}}$ Istituto Nazionale di Geofisica e Vulcanologia, Via di Vigna Murata 605, 00143 Roma, Italy \\ ${ }^{c}$ Department of Geology, University of California at Davis, One Shields Avenue, Davis, CA 95616, USA \\ d Department of Geosciences, National Taiwan University, P.O. Box 13-318, Taipei, Taiwan, ROC, 106
}

Received 15 January 2005; received in revised form 5 June 2005; accepted 30 August 2005

\begin{abstract}
We conducted detailed rock magnetic investigations on $36 \mathrm{~m}$ of drill core collected during Ocean Drilling Program Leg 195 at Hole $1202 \mathrm{~B}\left(24^{\circ} 48.24^{\prime} \mathrm{N}, 122^{\circ} 30.00^{\prime} \mathrm{E}\right)$, in the Southern Okinawa Trough, with the goal of extracting a reliable paleointensity signal with centennial resolution. An age-depth model was established from a chronology obtained by accelerator mass spectromety ${ }^{14} \mathrm{C}$ dating. The sedimentary section spans almost the entire Holocene (0-9.4 kyr) and exhibits sedimentation rates close to $400 \mathrm{~cm} / \mathrm{kyr}$. The magnetic properties are dominated by stable, pseudo-single domain magnetite. High-field hysteresis data and the grain-size sensitive ratio of anhysteretic remanent magnetization (ARM) to low field magnetic susceptibility indicate a narrow range of grain sizes and concentrations. Magnetic parameters vary by a factor of 4 thereby fulfilling the usual criteria for a relative paleointensity study. The relative geomagnetic paleointensity was obtained by normalizing the intensity of natural remanent magnetization (NRM) by the ARM and the low field magnetic susceptibility. Both normalizations yield nearly identical results $(r=0.89)$. Spectral analysis indicates that the record is not significantly affected by local environmental conditions. Comparison of this West Pacific paleointensity curve with other curves suggests a geomagnetic origin for the signal. Millennial-scale features of our record correlate to variations of the archeomagnetic dipole moment. This suggest that the sediments at Hole1202B recorded changes of the geomagnetic field over the studied time interval.
\end{abstract}

(C) 2006 Elsevier B.V. All rights reserved.

Keywords: Paleomagnetism; Paleointensity; Paleosecular variation; Holocene; Ocean Drilling Program; Site 1202; Okinawa Trough

\section{Introduction}

Millennial-scale variability in Holocene climate has been discussed in numerous studies (e.g., Bond et al., 1997; deMenocal et al., 2000; Bond et al., 2001) although

\footnotetext{
* Corresponding author. Fax: +1 3374825723.

E-mail address: richter@louisiana.edu (C. Richter).
}

the trigger for these events remains a matter of debate (e.g., Bond et al., 2001; deMenocal, 2001; Kukla, 2000). Understanding millennial and sub-millennial-scale climate variations requires high-resolution paleoclimatic data and the ability to correlate these records globally at millennial time scales (e.g., Channell et al., 2000; Stoner et al., 2000). Paleosecular directional variation over the last few thousand years has become an important dating tool in regional archeological research (e.g., Eighmy and 
Sternberg, 1990; Batt, 1997; Hedley, 2001; Nunez et al., 2000; Schnepp and Pucher, 2000), but changes in the strength of the Earth's magnetic field have the potential of becoming a global correlation tool at high resolution. Master curves at lower resolution have already been compiled successfully (Guyodo and Valet, 1996, 1999; Laj et al., 2000, 2004; Stoner et al., 2002), and the correlation between the geomagnetic dipole moment and the ${ }^{10} \mathrm{Be}$ production rate provides independent argument for the global validity of the paleointensity correlations (Frank, 2000; Christl et al., 2003; Carcaillet et al., 2004a, 2004b). Several paleointensity records have been tied to ice core chronologies (Stoner et al., 2000; Brachfeld et al., 2003), and it is becoming increasingly convincing that millennial scale variations of the geomagnetic field have the potential for global correlation (Laj et al., 2003).

In recent years an increasing number of sedimentary paleointensity records have been published (e.g., Thouveny et al., 2004; Brachfeld et al., 2003; Stoner et al., 2003; Horng et al., 2003; St-Onge et al., 2003; Channell and Raymo, 2003; Yamazaki, 2002; Channell et al., 2000, 2002; Snowball and Sandgren, 2002; Guyodo et al., 2001) in part because pass-through magnetometers are now widely available and u-channel sampling of long piston cores has become routine. Most cores recovered by the Ocean Drilling Program (ODP) and the IMAGES Program are now sampled with u-channels and measured at high resolution. The paleomagnetic study of

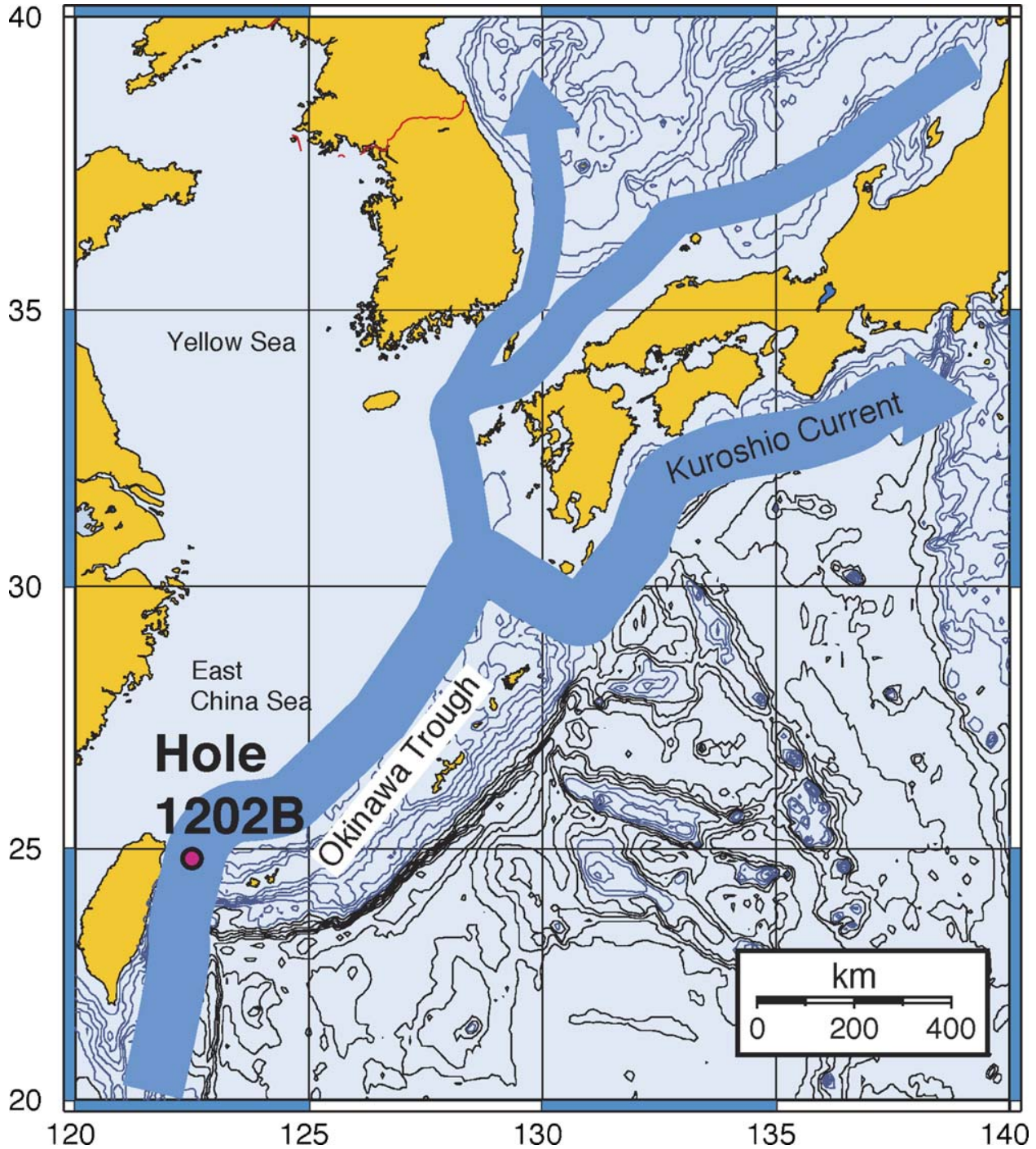

Fig. 1. Location of Site 1202 in the Southern Okinawa Trough and path of the Kuroshio Current. 
ancient geomagnetic field intensity has received significant attention with the recognition that field intensity variations not only can provide a global chronology but have implications for many aspects of earth science, such as the dynamics of the Earth's fluid core (e.g., Aldridge and Baker, 2003).

One of the objectives of Ocean Drilling Program Leg 195 was to acquire high-resolution climate proxy records from sediments deposited beneath the Kuroshio Current. Site $1202\left(24^{\circ} 48.24^{\prime} \mathrm{N}, 122^{\circ} 30.00^{\prime} \mathrm{E}\right)$ is situated in the Southern Okinawa Trough (Fig. 1) in $1274 \mathrm{~m}$ deep water. Sedimentation rates are high because of terrigenous input from the East China Sea shelf and Taiwan (Boggs et al., 1979; Lin and Chen, 1983; Chung and Chang, 1995). The East China Sea shelf was emergent during the last glacial maximum, and only the Okinawa Trough was submerged. The Okinawa Trough lies significantly above the carbonate compensation depth (CCD), unlike most parts of the Pacific. High sedimentation rates and the preservation of calcareous microfossils make Site 1202 an ideal target for obtaining a high-resolution record of the late Quaternary history of the Kuroshio Current.

Correlation among the four advanced hydraulic piston (APC) holes cored at this site could only be accomplished at a broad scale, and because of the lack of distinct features in the available physical properties records, a composite section (e.g., Hagelberg et al., 1992) could not be established. The shipboard scientific party of ODP Leg 195 decided after preliminary investigation to concentrate all scientific analysis on Hole 1202B. Composite sections from other APC holes of the Ocean Drilling Program show that there is typically a coring gap of varying extend between individual cores because of the drill ship's heave. APC cores from sediments from the African Margin, which are comparable to the Hole 1202B sediments, exhibit coring gaps of typically $1.5-2 \mathrm{~m}$, and they can in extreme cases be up to $9 \mathrm{~m}$ wide (Wefer et al., 1998). Preliminary biostratigraphic investigation (Salisbury et al., 2002) of core catcher samples from Site 1202 indicated that the sequence is younger than $127 \mathrm{ka}$, promising an ultra-high resolution section with sedimentation rates in the order of $320 \mathrm{~m} / \mathrm{kyr}$.

In this study, we investigate the top $36 \mathrm{~m}$ below seafloor (mbsf), or the last 9500 yrs of Hole 1202B. We present detailed rock magnetic data and demonstrate that the sediments preserve a high-resolution record of paleosecular variation and a paleointensity signal spanning almost the entire Holocene. A reliable geomagnetic signal could not be extracted from the deeper part of Hole 1202B (Venuti et al., 2005) probably because of the dissolution of fine-grained magnetite. The sediments consist of homogenous, slightly calcareous, bioturbated clayey silt with isolated sandy intervals and fine sand laminae. Sandy layers have been interpreted to be mostly detrital material, indicating episodes of turbidity current activity (Salisbury et al., 2002). The organic matter content is moderate and varies between $0.4 \%$ and $0.9 \%$ for the last $25 \mathrm{ka}$ (unpublished data, K.-Y. Wei). Small amounts of $\mathrm{H}_{2} \mathrm{~S}$ were discernable when opening the cores.

\section{Depth and age models}

The depth model is based on the original ODP scale of meters below seafloor (mbsf). Core expansion in recovered deep sea sediment cores occurs because of elastic rebound (Moran, 1997) and because of degassing of the cores. This leads to overlapping core sections and overlapping measurements at core breaks and consequently to inconsistencies during data analysis and representation. For Hole 1202B, a revised mbsf (rmbsf) scale was constructed by adding a constant offset $(18 \mathrm{~cm}$ on average) to each core to compensate for the amount of core overlap. Conversion between the two depth scales is straightforward (Venuti et al., 2005). Significant coring gaps may exist between Cores 195-1202B-1H, 2H, $3 \mathrm{H}$, and $4 \mathrm{H}$ or between 2.7 and $2.9 \mathrm{rmbsf}, 12.64$ and $12.65 \mathrm{rmbsf}, 22.15$ and $22.16 \mathrm{rmbsf}$, and 31.97 and 31.98 rmbsf. It is impossible to quantify the amount of missing material without the construction of a composite depth scale.

Biochronologic markers are scarce in the mostly clastic sedimentary unit. Only the absence of pink Globigerinoides ruber (last occurrence at $127 \mathrm{ka}$, Thompson et al., 1979; Cang et al., 1988; Wei et al., 2005) indicates that the sequence is younger than $127 \mathrm{ka}$ and suggests that the average sedimentation rate is at least $320 \mathrm{~cm} / \mathrm{ky}$. This estimate is consistent with the occurrence of a short reversed polarity interval in the lower part of the section (101-108 mbsf equivalent to 103-111 rmbsf) which we interpret as the Mono Lake excursion (ca. $28 \mathrm{ka}$; Benson et al., 2003) based upon our age model.

The age model for Hole 1202B was established from 11 AMS ${ }^{14} \mathrm{C}$ ages (Wei et al., 2005). More than 300 specimens of surface dwelling planktic foraminifera, including Globigerinoides spp. and Orbulina universa were picked from the $>250 \mu \mathrm{m}$ size fraction of 10 selected intervals where foraminifera were present in sufficient numbers. A scaphopod was also picked from a sample at 1.92 mbsf for dating. $\mathrm{CO}_{2}$ gas was obtained from the calcareous fossil skeletons and sent to the 


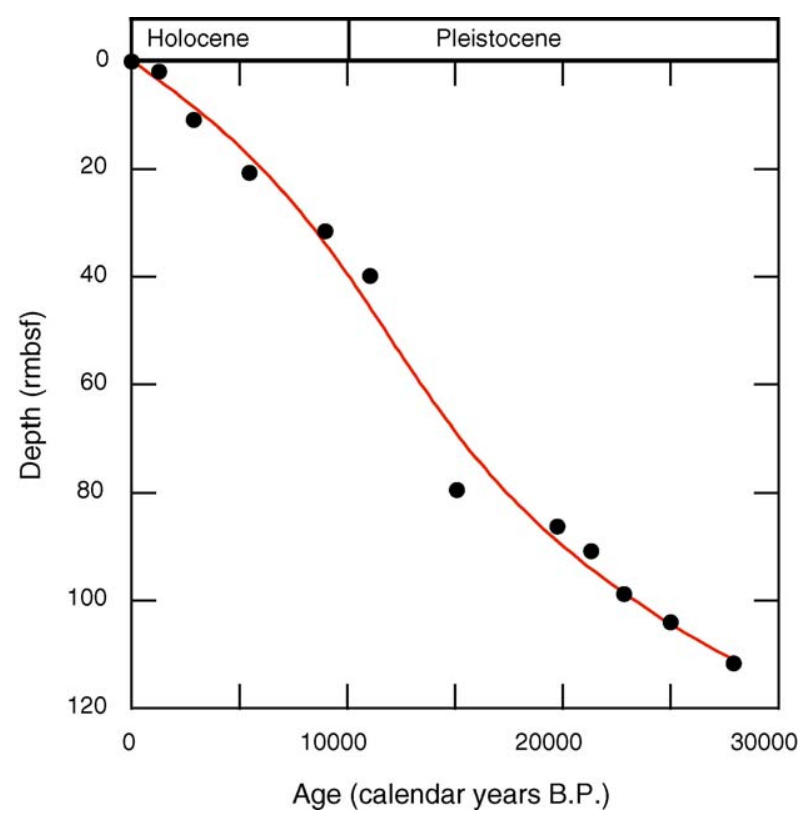

Fig. 2. Plot of calibrated ${ }^{14} \mathrm{C}$ ages versus depth at Hole 1202B. Age depth values were fit by a third-order polynomial (black line). Age $=0.95987+375.05$ Depth -4.1649 Depth $^{2}+0.027464$ Depth $^{3}$.

Rafter Radiocarbon Laboratory, Institute of Geological and Nuclear Sciences, New Zealand for AMS dating. The reported ${ }^{14} \mathrm{C}$ ages have been converted to "calendar ages" using the CALIB rev 4.4 Program (http://radiocarbon.pa.qub.ac.uk/calib/). We adopted a $\Delta R=35 \pm 25 \mathrm{yr}$ (the local difference in reservoir age from $400 \mathrm{yr}$ in the southern Okinawa Trough) as determined from annually banded corals of Ishigaki Island (Hideshima et al., 2001). The calibrated ages were then converted into thousand years BP (ka before AD 1950). For those conventional radiocarbon ages older than 20,265 yr BP, the dates were converted to calendar ages using the polynomial equation of Bard (1998): [cal $\mathrm{BP}]=-3.0126 \times 10-6 \times\left[{ }^{14} \mathrm{C}\right.$ age BP $]{ }^{2}+1.2896 \times\left[{ }^{14} \mathrm{C}\right.$ age BP] -1005 . Age-depth values for the last 28,000 calibrated radiocarbon years were fit by a third-order polynomial ( $r=0.99$; Fig. 2). The average sedimentation rate for the $0-42.9-\mathrm{ka}$ interval at Site 1202 is $324 \mathrm{~cm} / \mathrm{kyr}$, with the maximum sedimentation rate maximum $(\sim 515 \mathrm{~cm} / \mathrm{kyr})$ at the end of the Late Pleistocene, coinciding with the end of the last glaciation. The average sedimentation rate in the Holocene is $394 \mathrm{~cm} / \mathrm{kyr}$. The age of individual sample points was estimated by the third-order polynomial fit of the depth- ${ }^{14} \mathrm{C}$ age relationship (Fig. 2).

Our age model assumes zero age at zero depth, but it is possible that the topmost part of the Holocene is missing.

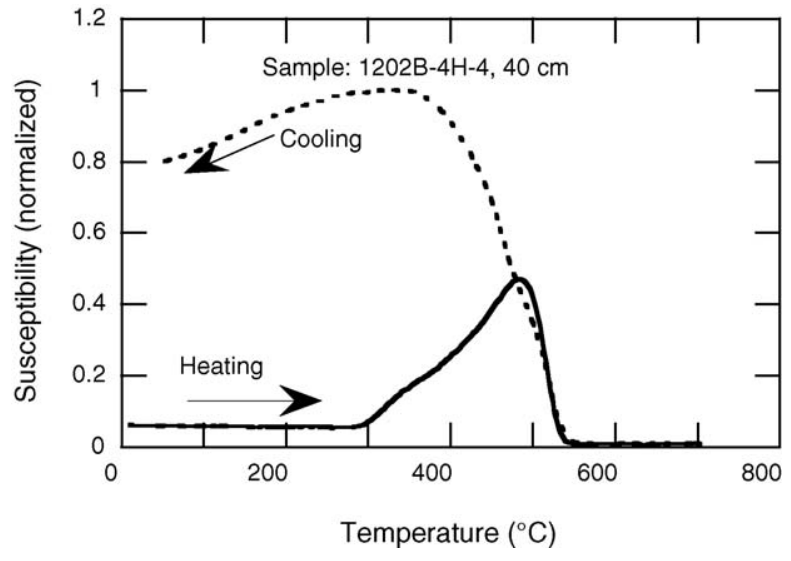

Fig. 3. Temperature-dependence of low-field magnetic susceptibility for a representative sample. The thermomagnetic behavior is characterized by low susceptibilities that increase at around $300^{\circ} \mathrm{C}$ probably because of the formation of magnetite from sulfites.

A third-order polynomial curve fit of the topmost four age data (representing the Holocene) without a zero-age at zero-depth constrain gives an age of $1081 \mathrm{yr} \mathrm{BP}$ at zero depth $(r=1)$ and a linear curve fit of the topmost two age determinations gives an age of $954 \mathrm{yr}$ BP at zero depth. Based on these calculations it is possible that the last $\sim 1000 \mathrm{yr}$ BP are missing from the Hole 1202B record.

\section{Rock magnetic properties}

Measurements of the temperature dependence of magnetic susceptibility, up to a maximum temperature of $700^{\circ} \mathrm{C}$, were performed with a furnace-equipped Kappabridge KLY-3 susceptibility meter (Hrouda, 1994) at the Istituto Nazionale di Geofisica e Vulcanologia in Rome, Italy. The thermomagnetic results (Fig. 3) show a low magnetic susceptibility that exhibits a pronounced peak between $300^{\circ}$ and $500^{\circ} \mathrm{C}$, indicating the formation of a new magnetite phase probably from sulfites. The major decrease in magnetic susceptibility at high temperatures indicates a Curie temperature of about $540^{\circ} \mathrm{C}$. This is $40^{\circ} \mathrm{C}$ lower than the Curie temperature of pure magnetite and is indicative of low-titanium magnetite. Although the susceptibility is close to zero above $540{ }^{\circ} \mathrm{C}$ it is difficult to draw conclusions about the carrier of magnetic remanence from this type of measurement.

Hysteresis properties were determined on 49 evenlyspaced samples using a Princeton Measurements alternating gradient magnetometer in the paleomagnetism laboratory at the University of California at Davis. Hysteresis loops indicate saturation fields well below $200 \mathrm{mT}$ and coercivities typical for magnetite (Fig. 4a). 

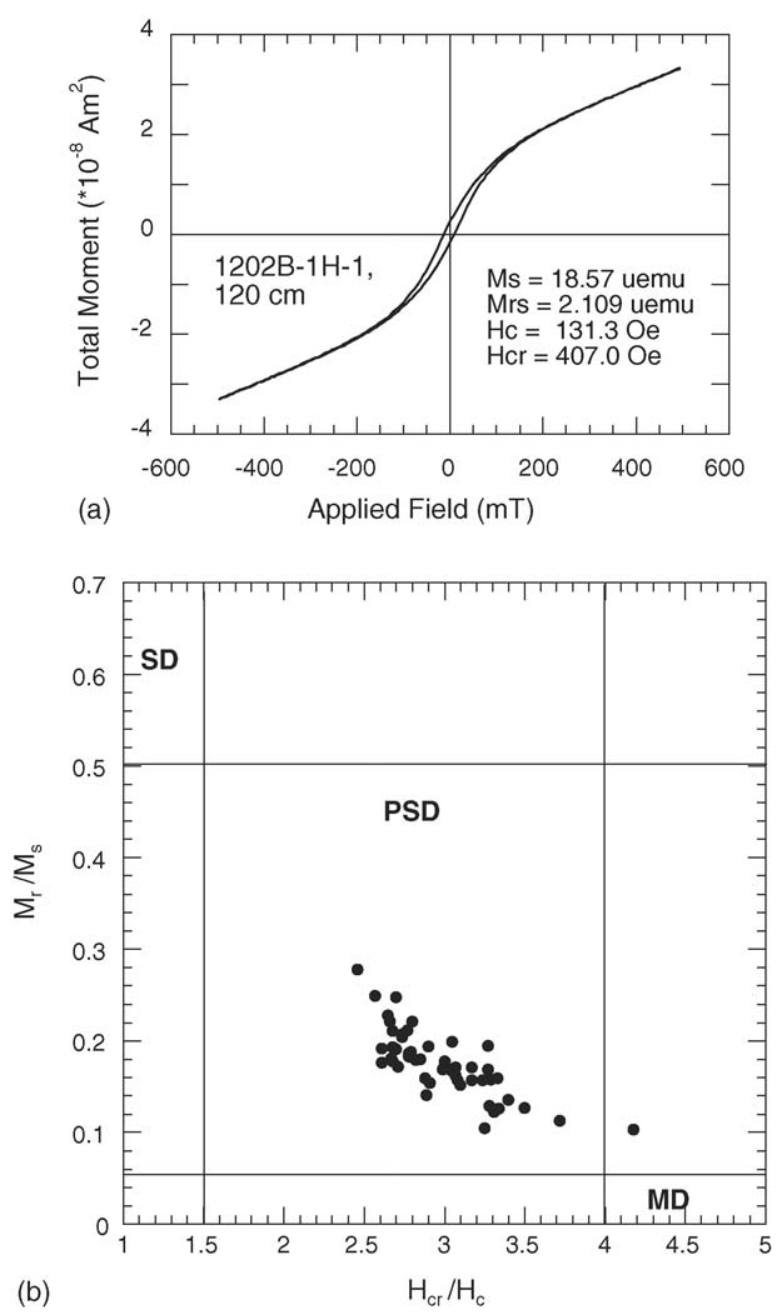

Fig. 4. (a) Hysteresis loops show saturation fields $<200 \mathrm{mT}$ and coercivities typical for magnetite. (b) Hysteresis ratios display the pseudosingle domain state of the magnetic carrier (Day et al., 1977) and vary within a narrow range along a grain size mixing line.

The ratios of coercivity of remanence over coercivity $(\mathrm{Hcr} / \mathrm{Hc})$ and saturation remanence over saturation magnetization (Mrs/Ms) are sensitive to variations in grain size (Day et al., 1977; Dunlop, 1986). Our detailed measurements of magnetic hysteresis properties show little variation in magnetic grain size of the clay-rich sediments of Hole 1202B. A plot of Mrs/Ms versus Hcr/Hc (Day et al., 1977) shows that most magnetic carriers fall in the pseudo-single domain field of magnetite (Fig. 4b). Measurements of the S-ratio ( $\mathrm{S}=-\mathrm{IRM}$ $300 \mathrm{mT} / \mathrm{SIRM} 1.2 \mathrm{~T}$ ) vary between 0.88 and 1.00 , as expected for ferrimagnetic minerals such as (titano-) magnetite. These rock magnetic results indicate that the magnetic signal in the clay-rich sediments is dominated by (low-titanium) magnetite.

\section{Continuous magnetic measurements, natural remanent magnetization (NRM), and magnetic inclinations}

We measured $36 \mathrm{~m}$ of continuous u-channel samples (e.g., Tauxe et al., 1983), collected from the working half of the Hole 1202B cores, with a 2G Enterprises Model 755R cryogenic magnetometer housed in a shielded room at the University of California, Davis. The cores were initially demagnetized at $20 \mathrm{mT}$ and measured on board the JOIDES Resolution using another $2 \mathrm{G}$ longcore magnetometer (Salisbury et al., 2002). We demagnetized the u-channels subsequently using a three-axis alternating field (af) at 20, 30, 40, 50, and $60 \mathrm{mT}$ and measured every $1 \mathrm{~cm}$ to obtain detailed records of the directions and intensity of the natural remanent magnetization (NRM). Because the response curve of the pickup coils of the magnetometer has a width of $4.5 \mathrm{~cm}$ (Weeks et al., 1993), only every fourth measurement yields an independent value. For the Holocene sedimentation rates at Site 1202, this translates to a 10-year resolution. Laboratory experiments by Katari et al. (2000) demonstrate that postdepositional physical realignment of magnetic grains is insignificant. We therefore assume that the NRM is syndepositional, i.e., acquired and preserved within a few centimeters of the sediment surface. An anhysteretic remanent magnetization (ARM) was imparted using a peak alternating field of $100 \mathrm{mT}$ and direct bias field of $0.05 \mathrm{mT}$ and was subsequently af demagnetized at the same levels as the NRM. The ARM was converted into ARM susceptibility (kARM) by normalizing with the applied direct field. Measurements of the isothermal remanent magnetization (IRM), although frequently an excellent normalizer for paleointensity studies, could not be performed on the u-channel samples because of flux jumps associated with the pass-through measurements. We measured the low-field magnetic susceptibility $(\mathrm{k})$ at 1-cm resolution using a Bartington susceptibility meter and a field surface probe. This process required opening of the u-channels to place the probe directly onto the sediment. The u-channel susceptibility data (Fig. 5a) compare well with the shipboard data that were measured on the whole cores using a 8-cm sensor loop (Fig. 5b) onboard the JOIDES Resolution within hours after recovery (Salisbury et al., 2002). An exception are the topmost $5 \mathrm{~m}$, where shipboard data exhibit relatively low susceptibilities compared to the u-channel data. This is likely caused by a dilution of the signal by the high water content of the sediment near the sediment-water interface as measured in the whole cores compared to the u-channels which were taken from the de-watered split cores several months later. 

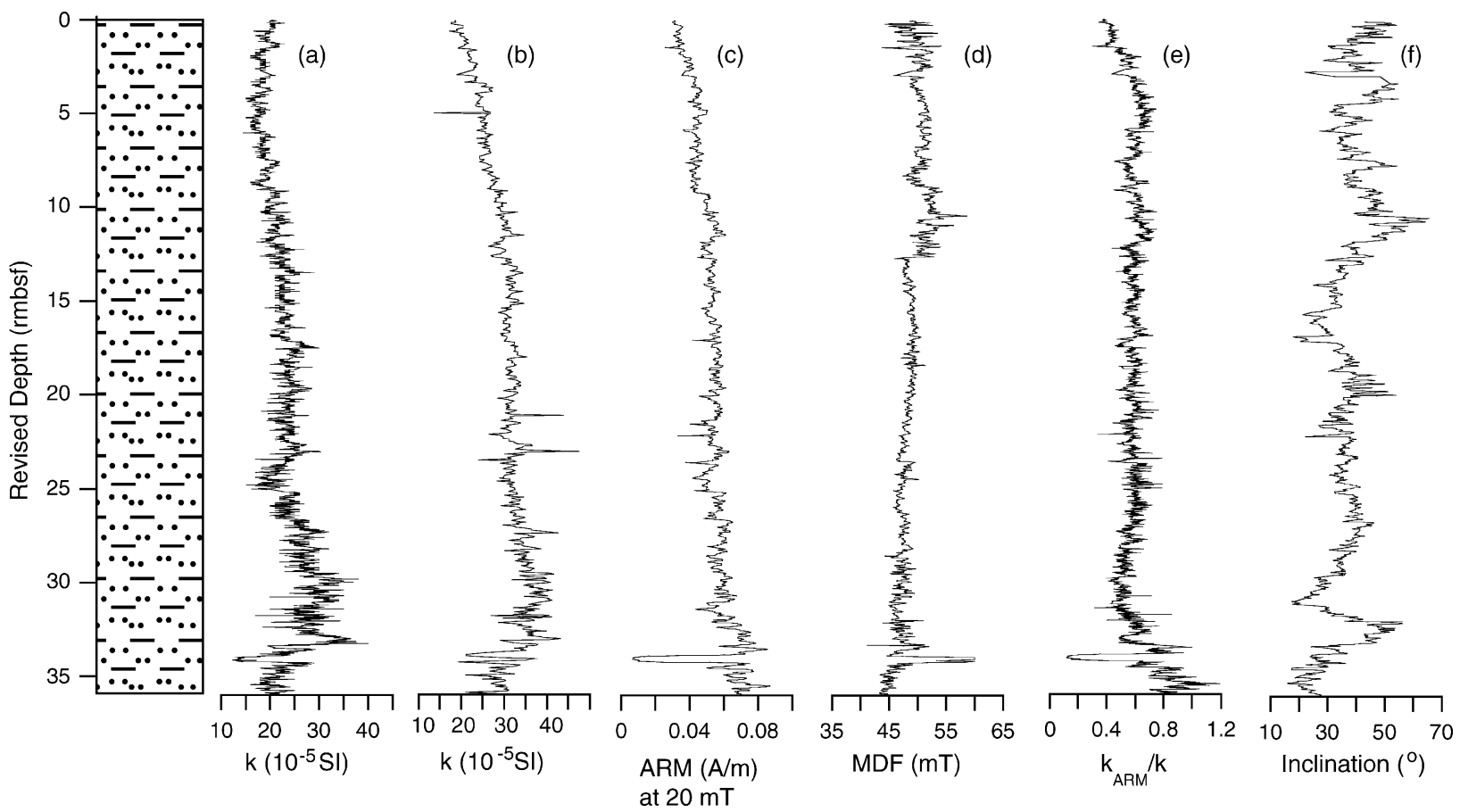

Fig. 5. Lithology (pattern represents clayey silt) and downcore variations of magnetic parameters from 0 to 36 rmbsf at Hole $1202 B .:$ (a) low-field magnetic susceptibility (k) measured on u-channels, (b) low-field magnetic susceptibility measured on whole cores directly after recovery, (c) ARM demagnetized at $20 \mathrm{mT}$, (d) median destructive field (MDF) of remanence, (e) kARM/k ratio, and (f) magnetic inclination. Concentration dependent parameters and grain size proxy remain fairly constant throughout the section.

The variation in the concentration of magnetic carriers was investigated by using the concentrationdependent records of ARM and magnetic susceptibility (Fig. 5a-c). Except for a 35-cm long interval with anomalous behavior around 33.35 mbsf, the variation of both parameters does not exceed a factor of 4 , a value that is well within the desirable range for relative paleointensity determinations (Tauxe, 1993).

Variations in the coercivity of the magnetic minerals were investigated with the median destructive field (MDF), which is the alternating field necessary to reduce the NRM to $50 \%$ of the initial value (Fig. 5d). The MDF has a fairly high mean value of $45.23 \mathrm{mT}$ with a standard deviation of $6.0 \mathrm{mT}$. The MDF shows only one significant increase in the short anomalous interval from 33.35-33.70 mbsf, which could be caused by an increase in high-coercivity minerals. The kARM/k ratio (Fig. 5f) can be used as estimate of relative variations in magnetic grain size if the magnetization is dominated by magnetite. The downcore variation of the $\mathrm{kARM} / \mathrm{k}$ ratio is very small (mean: 0.586; standard deviation: 0.002) which demonstrates that the magnetic grain sizes do not change significantly throughout the section.
We calculated the characteristic remanent magnetization (ChRM) of the magnetic vector by averaging the directions obtained at the five demagnetization steps. We were not able to reconstruct the magnetic declination because the advanced piston cores are not azimuthally oriented at shallow subsurface depth. The inclination is $37.3^{\circ}$ on average (Fig. 5f), within $1^{\circ}$ of the expected $36.1^{\circ}$ at that site latitude. Representative orthogonal vector demagnetization diagrams of the uchannels (Fig. 6) indicate the presence of a well defined, stable characteristic remanence over the entire interval. Principal component analyses (Kirschvink, 1980) yielded an average angular deviation (MAD) of $2.3^{\circ}$ with a standard deviation of $1.2^{\circ}$. Between $20 \%$ and $40 \%$ of the remanence remains after peak alternating fields of $60 \mathrm{mT}$. Two discrete samples from nearby Hole 1202A that were demagnetized within hours after recovery are displayed in Fig. 6e and f. Although much of the sediment is affected by a secondary viscous NRM component acquired during the coring, transport, sampling, and storage process, this overprint was readily removed in alternating fields of $<20 \mathrm{mT}$ (Fig. 6). 
(a)

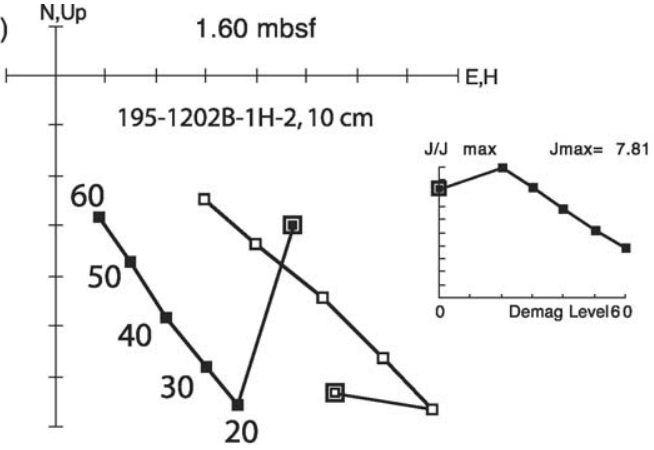

(c)

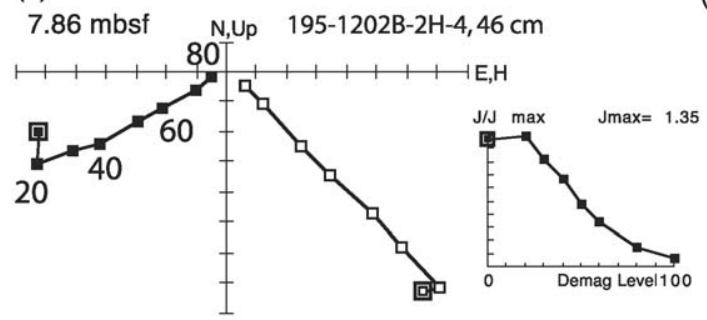

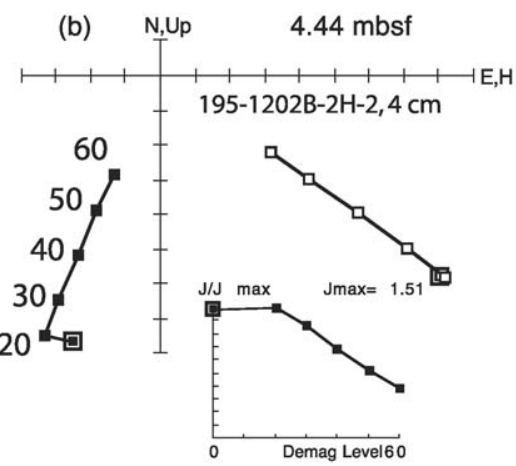

(d)

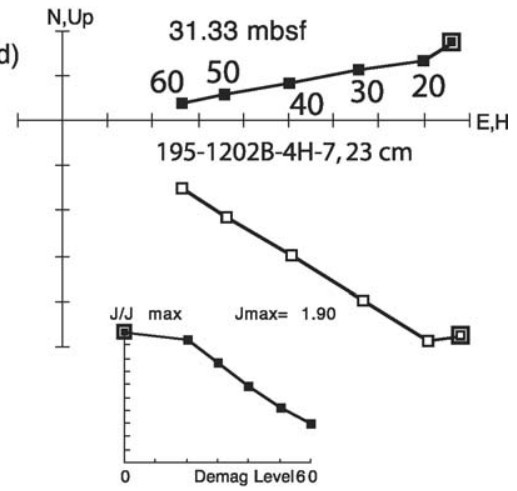

(e)

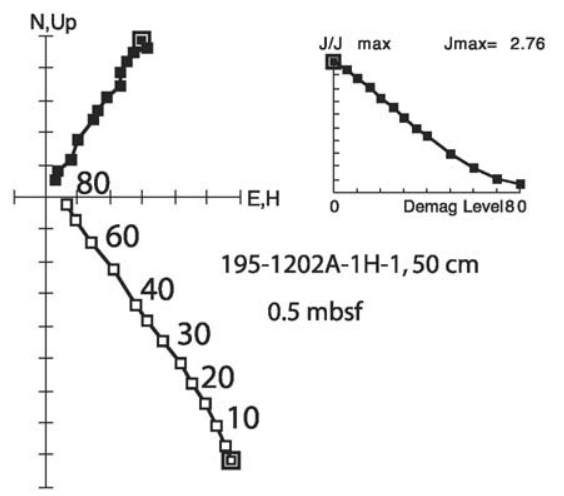

(f) $195-1202 \mathrm{~A}-4 \mathrm{H}-3,48 \mathrm{~cm}$

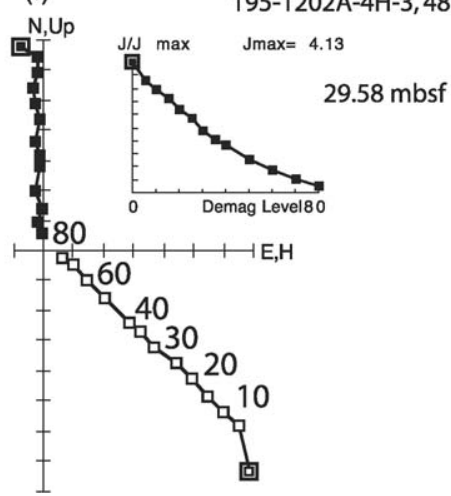

Fig. 6. Vector component diagrams with normalized intensity decay plots of alternating-field (AF) demagnetization behavior for four representative samples from Holes 1202A and 1202B. Open (closed) symbols represent projections on the vertical (horizontal) plane.

As expected for the Holocene, all inclinations are positive, representing the latest part of the Brunhes Normal Chron (Fig. 5f). The magnetic inclination record shows distinct large-scale paleosecular variation features that can be used to establish chronologies in cores that cannot be dated otherwise. However, we lack a local record that would allow us to validate the secular variation record. What we can do is compare our record with two well-dated high-resolution records from North America, Elk Lake (Sprowl and Banerjee, 1989) and Fish Lake (Verosub et al., 1986). When we apply the established age model for Hole 1202B and smooth the inclination record ( 21 points), we find that the inclination record from Hole 1202B has features with the same amplitude as the other two records, suggesting that Site 1202 has faithfully recorded the local secular variation (Fig. 7).

\section{Relative paleointensity determinations}

The rock magnetic characteristics, including welldefined magnetization component carried by magnetite, pseudo single domain (PSD) state of the magnetite, and 


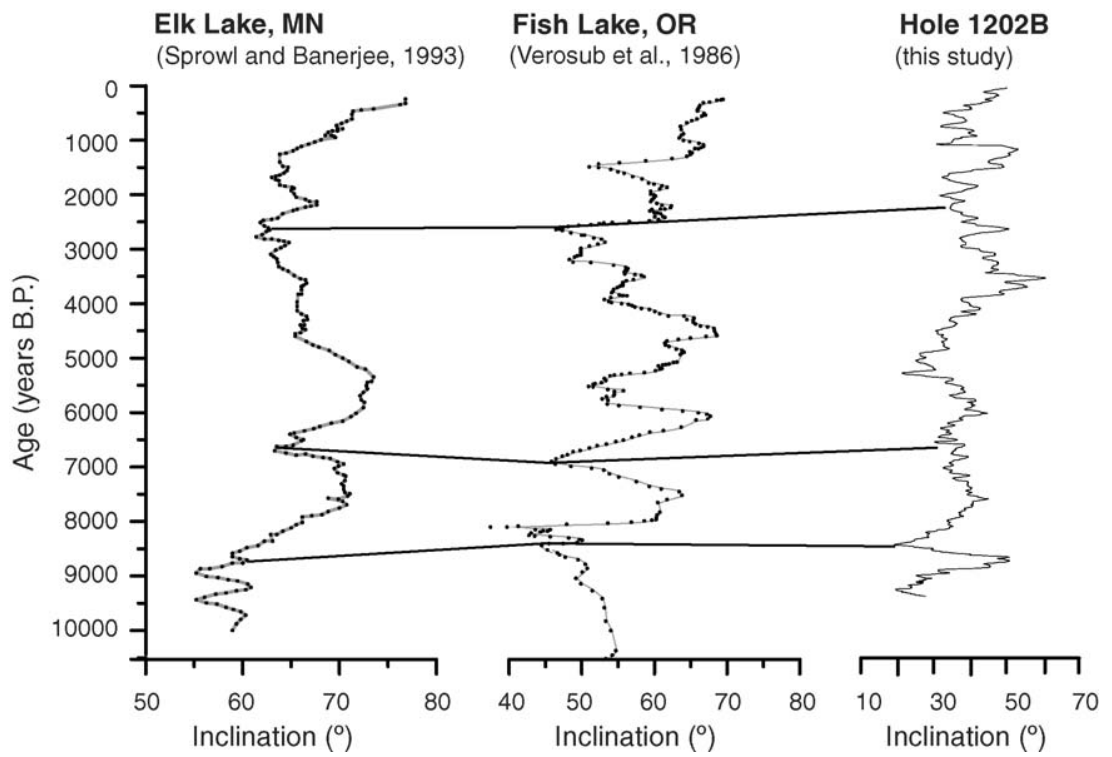

Fig. 7. Comparison of the Hole 1202B paleosecular variation of magnetic inclination (21 point smoothed) with data from North America. Several large-scale features can be correlated across the records.
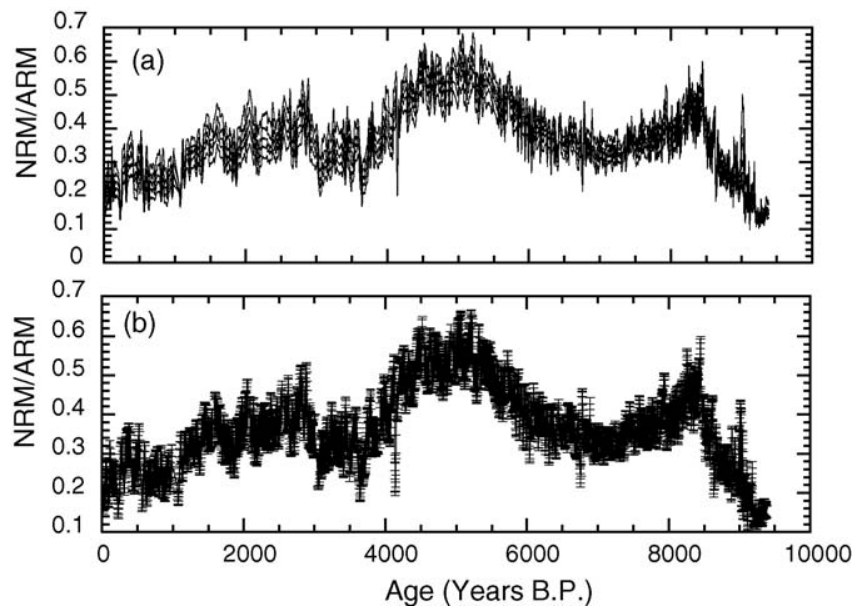

Fig. 8. (a) NRM/ARM after AF demagnetization of both NRM and ARM at peak fields of 20, 30, 40, 50, and 60 mT. (b) Mean values of NRM/ARM measurements and associated standard deviations. Error bars indicate \pm 1 standard deviation about each mean.

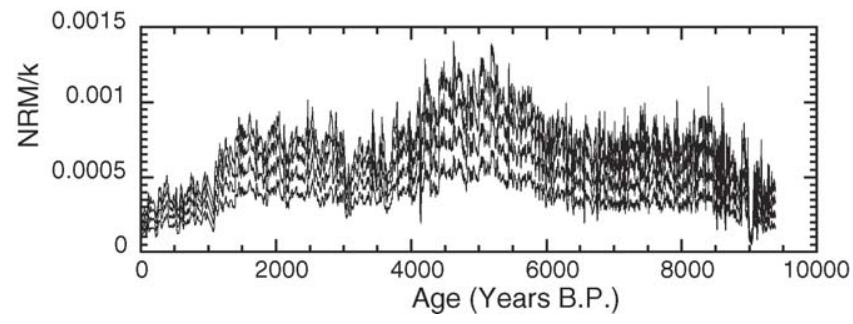

Fig. 9. NRM/k after demagnetization at peak fields of 20, 30, 40, and $50 \mathrm{mT}$. 


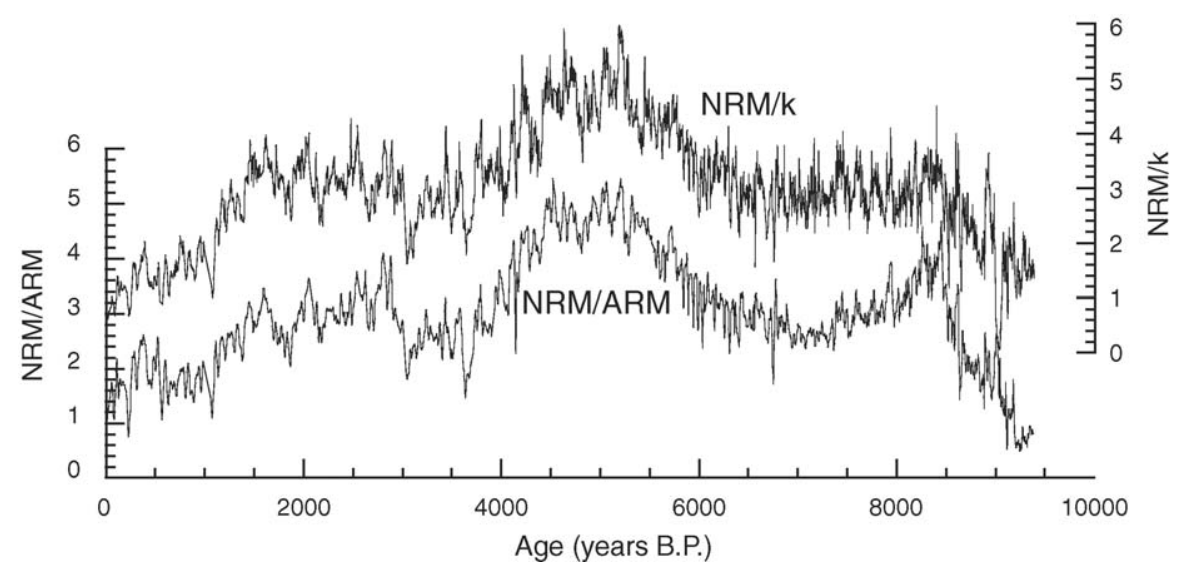

Fig. 10. Comparison between the ARM and k normalized NRM. Both records are normalized to unity to allow direct comparison. The correlation between NRM/ARM and NRM/k is superb $(r=0.89)$.

variation of less than a factor of 10 in the magnetic concentration satisfy the usual criteria for paleointensity studies (King et al., 1983; Tauxe, 1993). Paleointensity proxies are constructed by normalizing the NRM by the appropriate normalization parameter, one that activates the same grain population as the one that carries the remanence. ARM, saturation isothermal magnetization (SIRM), and susceptibility have all been successfully used as a proxy for changes in magnetite concentration (see review by Valet, 2003). However, a consensus on a preferred normalizer has not been reached. It appears that any normalizer can be successfully used if the sediment is magnetically homogenous and if the characteristic component of magnetization has been isolated (Levi and Banerjee, 1976; Valet and Meynadier, 1998). In a recent review, Valet (2003) suggested the use of multiple normalizers and specifically of normalizers that co-vary with the NRM. However, ARM-normalized records should be preferred because the ARM activates the same PSD and single domain (SD) magnetite carrying the NRM signal.

Stacked values of NRM/ARM determined from af demagnetization of NRM and ARM in peak fields of $20,30,40,50$ and $60 \mathrm{mT}$ are displayed against age in Fig. 8a. We calculated the arithmetic mean of these values and used the standard deviation about each mean to estimate the error associated with the mean (Fig. 8b). Normalization of the NRM at 20,30,40, and $50 \mathrm{mT}$ with susceptibility (Fig. 9) shows the same variability as the ARM normalization. To be able to compare both normalized records, we standardized each value by subtracting the arithmetic mean and dividing by the standard deviation (Fig. 10). The similarity of the results obtained by these two normalizers is often considered a good indication of the reliability of the paleointensity record (Tric et al., 1992; Meynadier et al., 1992). A direct comparison between the records of standardized mean NRM/ARM and standardized mean NRM/k (Fig. 10) demonstrates that they are closely correlated. The linear correlation between these paleointensity estimates has a correlation coefficient $(r)$ of 0.89 .

Although all of the established criteria for relative paleointensity determinations appear to be satisfied, it is possible that the record is influenced by environmental variations such as lithology and grain size, rather than by geomagnetic variations. Our record is too short to assess Milankovitch-scale climatic influences, however, centennial and millennial-scale cycles should be revealed if they exist. We performed spectral analysis of the two determinations of relative paleointensity with the Analyseries software (Paillard, 1996) using the Blackman Tukey method with a Bartlett window. The power spectra of both paleointensity proxies are very similar and reveal no significant periodicities (Fig. 11a and b). On the other hand, power spectra of the ARM and the susceptibility records are characterized by power at 2.47 and $0.5 \mathrm{ka}$, respectively (Fig. $11 \mathrm{c}$ and d). While the origin of these millennial scale variations requires further investigation, it is evident that they have no influence on the paleointensity estimates.

To further demonstrate that the paleointensity normalization is not substantially affected by lithological or environmental factors, we computed the cross coherence spectra between our relative paleointensity estimates and related mineral magnetic parameters (Fig. 11e and f). The coherence function between NRM/ARM and $\mathrm{k}$ and between NRM/k and ARM reveals several peaks above the $95 \%$ confidence level. However, these occur mostly at higher frequencies and are not associated with the 2.47 and $0.5 \mathrm{ka}$ cycles determined in the susceptibility 

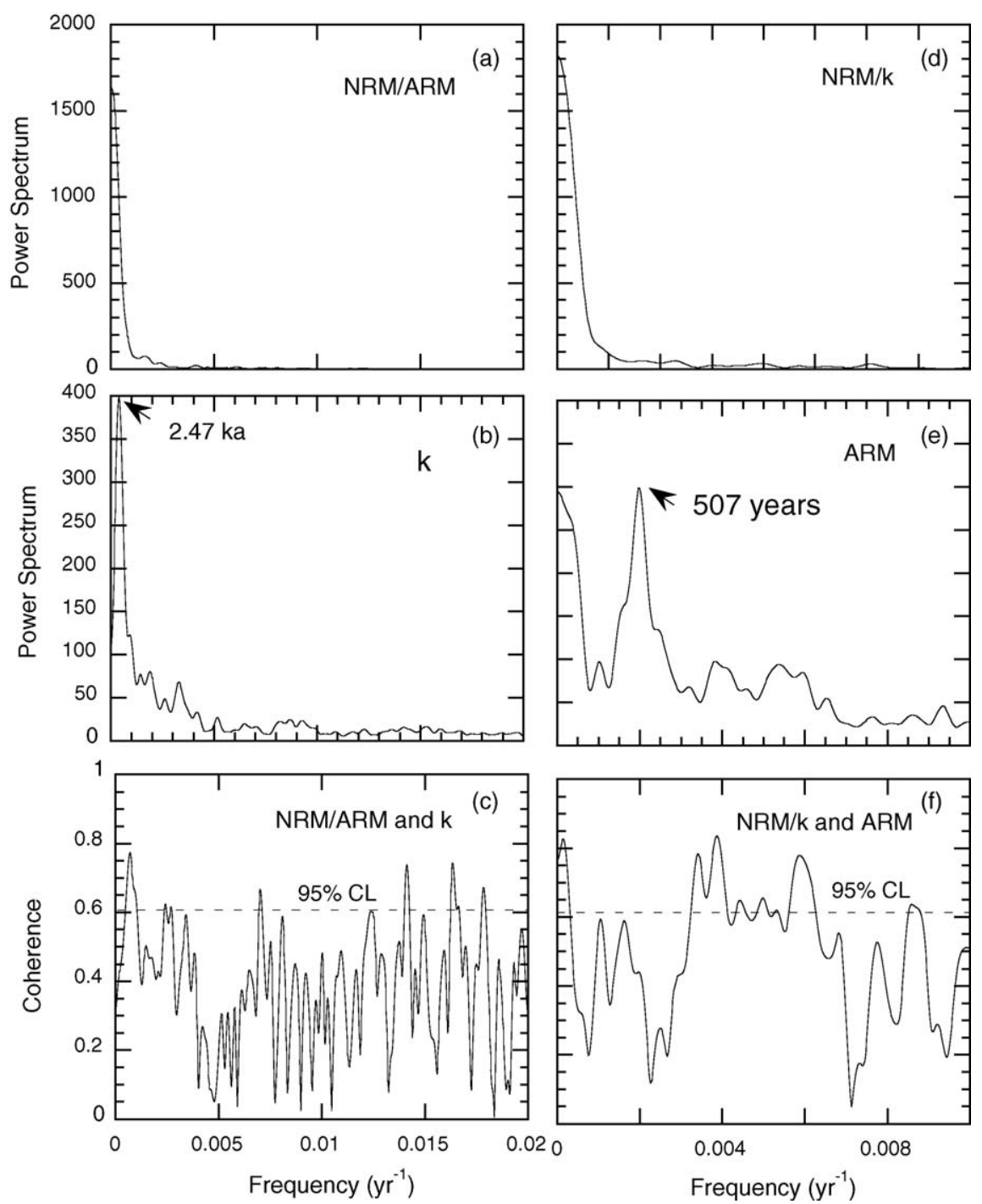

Fig. 11. Power spectra of the paleointensity records, k, and ARM and coherence spectra between the two determinations of paleointensity and concentration-dependent rockmagnetic parameters. Neither of the paleointensity normalizations shows power at any frequency. ARM and k are dominated by millennial-scale cycles and the cross functions do not show power at the frequency of the ARM or k. Both paleointensity estimates are apparently free of any environmental signal.

and the ARM records. Zhao et al. (2005) found a sea surface temperatures rise from $24^{\circ} \mathrm{C}$ to $25.5^{\circ} \mathrm{C}$ during the 9.5 to $8 \mathrm{ka}$ interval, but otherwise no major climatic signals or sedimentological characteristics have been detected. Based on our analyses and the results from Zhao et al. (2005), we conclude that the normalization with both ARM and susceptibility efficiently remove the climatic component of the record and that local environmental factors do not have a strong impact on our paleointensity estimates. However, we cannot entirely eliminate the possibility of a large scale climatic influence.
In summary, compliance with the most commonly applied mineral magnetic criteria, paleomagnetic stability, agreement between the results of two paleointensity normalizations (NRM/ARM and NRM/k), and lack of an environmental signal in the power spectra of the normalized records indicate that the Hole 1202B record meets all reliability criteria for relative paleointensity records (e.g., Tauxe, 1993). Although there is very little discrepancy between the ARM and the k normalizations, we regard the ARM normalized record (Fig. 12) as the best paleointensity estimate at Hole 1202B because the ARM is a better measure of the total amount of 

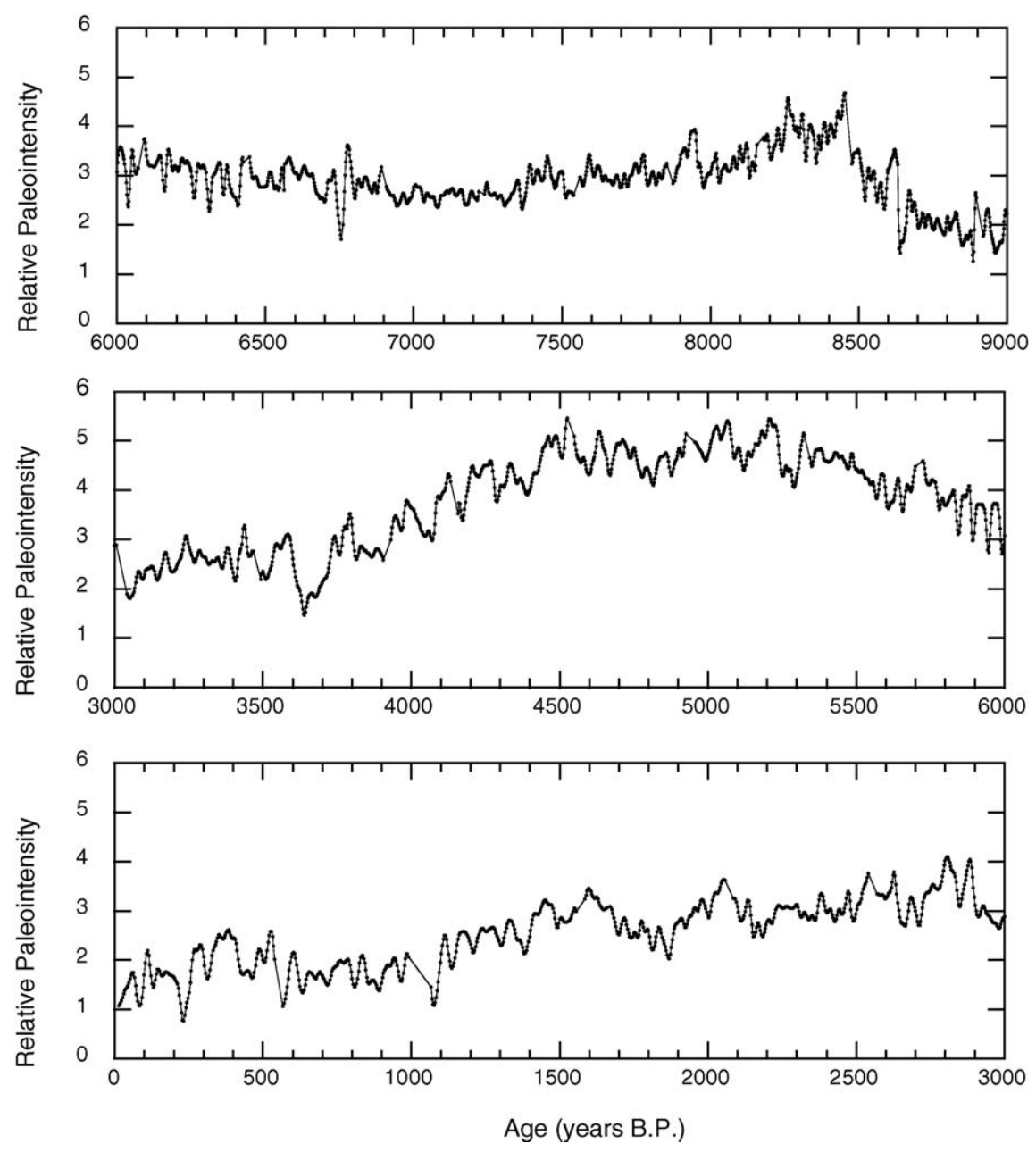

Fig. 12. The relative paleointensity record at Hole 1202B. Data are ARM normalized. Relative paleointensity increased rapidly from 9000 to 8400 B. P., increased further from 6000 to 5300 B.P., and has been declining over the last 4500 years.

magnetic material than the low-field magnetic susceptibility.

\section{Paleointensity during the last $9400 \mathrm{yr}$}

Comparison of the Hole 1202B paleointensity record with other Holocene high-resolution records provides the most powerful test whether the paleointensity features were globally recorded and therefore represent changes in the geomagnetic field. Short-term centennial and decadal-scale features such as observed at Hole 1202B are not resolved in low-resolution composite records such as the SINT200 (Guyodo and Valet, 1996), the SINT 800 (Guyodo and Valet, 1999), the GLOPIS-75 (Laj et al., 2004), or archeointensity data (McElhinny and Senanayake, 1982; Yang et al., 2000). High-resolution Holocene records have been reported from North America (e.g., Brachfeld and Banerjee,
2000), the Mediterranean Region (e.g., Genevey et al., 2003; Frank et al., 2003 and summary therein), northern Europe (Snowball and Sandgren, 2002), and Antarctica (Brachfeld et al., 2003, Palmer Deep). Hole 1202B represents the first high-resolution Holocene record from east Asia and therefore no suitable records are available for comparison. We compare our paleointensity record to the GLOPIS-75 (Laj et al., 2004), the archeomagnetic records from McElhinny and Senanayake (1982), the synthetic record from Ohno and Hamano (1993), and a high-resolution record from Fish Lake, Oregon (Verosub, unpublished data) (Fig. 13).

The paleomagnetic record from Fish Lake, Oregon, is dated by a series of radiocarbon analyses and tephra chronology. Magnetic remanence is stable and strong and carried by pseudo-single-domain magnetite (Verosub et al., 1986). Although it is a lake record from a site tens of thousands of kilometers away both records 


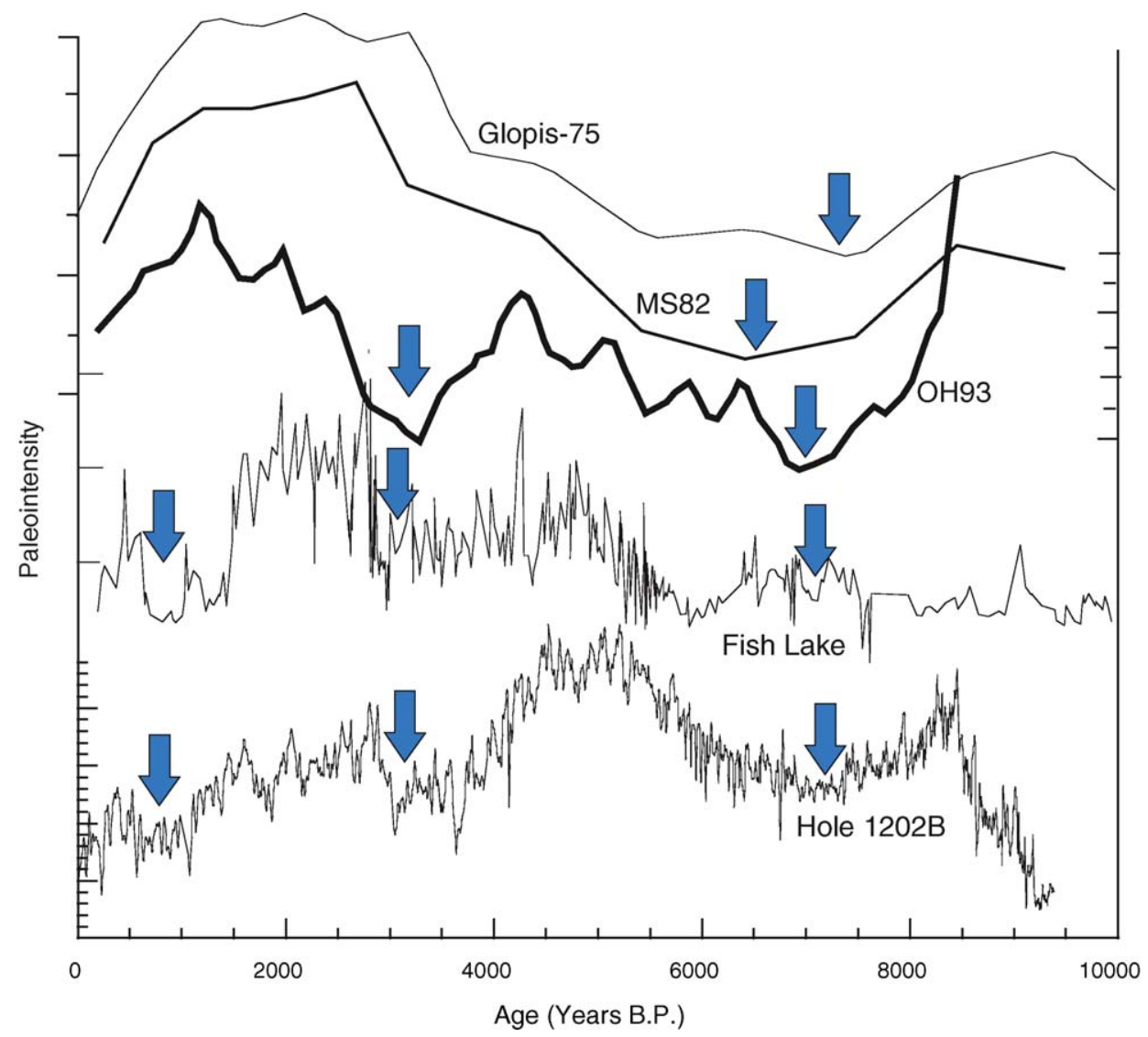

Fig. 13. Comparison of the relative paleointensity record from Hole 1202B with the Fish Lake, Oregon, record (Verosub, unpublished data). Also shown are two low resolution records, the dipole moment determined from archeological hearths (MS82) McElhinny and Senanayake (1982) and the NAPIS-75 paleointensity stack (Laj et al., 2004). OH93 is the synthetic record from Ohno and Hamano (1993). Arrows mark intensity lows that correlate across the records.

are similar in shape and amplitude during the last 7000 yr B.P.. Prior to 7000 yr B.P. the Fish Lake record is relatively flat but the Hole 1202B record continues to show variations (Fig. 13). The most significant difference between the two paleointensity curves is the sharp decrease in paleointensity between 5 and $3.5 \mathrm{ka}$ at Hole 1202B.

The GLOPIS-75 and the archeomagnetic record (McElhinny and Senanayake, 1982) correlate well with each other and show several of the large-scale Hole 1202B paleointensity features. The field decay during the last $2500 \mathrm{yr}$ and the paleointensity low around $7 \mathrm{ka}$ B.P. can be correlated between these records. The most significant difference between the GLOPIS75/archeomagnetic curve and the Hole 1202B record again occurs at around $5 \mathrm{ka}$, where a pronounced paleointensity peak is recorded at Hole 1202B but not in the global lower-resolution records.
The synthetic record (Ohno and Hamato, 1993) shows the closest similarity to the Hole 1202B paleointensity record. Most major features are represented in both curves, even the intensity decay between 5 and $3.5 \mathrm{ka}$.

Although the paleointensity record does not agree with every large-scale feature of other paleointensity records, many common features can be detected. However, we do not expect to obtain complete agreement between the low-resolution records and the relative paleointensity estimates determined at Hole 1202B. A comparison of high-resolution Holocene records from different parts of the globe (e.g., Brachfeld and Banerjee, 2000: North America; Snowball and Sandgren, 2002: Northern Europe; compilation in Frank et al., 2003, for Central Asia, Bulgaria, Israel, Greece, and Egypt) demonstrates that there is a wide variability between the shape of the individual records. This is not surprising because resolution, sedimentary environment (deep ocean, varves, 
lakes), lithology, and geographic position are significantly different.

\section{Conclusions}

We presented a high-resolution Holocene paleosecular variation and relative paleointensity record from ODP Hole 1202B in the Southern Okinawa Trough. Age control was provided by AMS radiocarbon ages and shows extremely high average sedimentation rates on the order of $400 \mathrm{~cm} / \mathrm{kyr}$, offering the opportunity to determine the field variations for this time period with centennial or even decadal resolution. The magnetic carrier mineral is (low-titanium) PSD magnetite with a limited range of grain size variation. Relative paleointensity estimates using the ARM and the low-field susceptibility normalizations are almost identical $(r=0.89)$. Spectral analyses show no apparent rock magnetic, climatic, or lithological influence. Because the ARM activates the same magnetite population that carries the NRM signal, we selected the ARM as the preferred normalizer for the Hole 1202B sediments.

The comparison between the Hole 1202B, GLOPIS75 (Laj et al., 2004), Fish Lake (Verosub, unpublished data), archeomagnetic (McElhinny and Senanayake, 1982), and synthetic (Ohno and Hamato, 1993) paleointensity records shows several significant discrepancies, especially around $5 \mathrm{ka}$, however, some major features correlate across the various records.

Our results confirm the highly oscillatory nature of the geomagnetic field intensity during the last $10 \mathrm{ka}$. The observed fluctuations are smooth and, as expected for a random process, the power spectrum reveals no periodicity (Fig. 11a and d).

Although we only obtained the u-channel record of one hole, the stability of the ChRM and the correlation with records from other regions suggest that Hole 1202B contains a reliable high-resolution record of paleosecular variation and relative paleointensity.

\section{Acknowledgements}

This research used samples and data provided by the Ocean Drilling Program (ODP). ODP is sponsored by the U.S. National Science Foundation (NSF) and participating countries under management of Joint Oceanographic Institutions (JOI), Inc. We gratefully acknowledge JOI for a JOI/USSAC (U.S. Science Advisory Committee) grant to C. R. that provided funding for this work. Careful reviews by Will Sager and an anonymous reviewer greatly improved the manuscript. We acknowledge numerous discussions with the Leg 195 Shipboard
Scientific Party and the highly professional support of the ODP technicians and the drill crew of the JOIDES Resolution during Leg 195, without whom this research would not have been possible.

\section{References}

Aldridge, K., Baker, R., 2003. Paleomagnetic intensity data: a window on the dynamics of Earth's fluid core? Phys. Earth Planet. Int. 140, 91-100.

Bard, E., 1998. Geochemical and geophysical implications of the radiocarbon calibration. Geochim. Cosmochim. Acta 62, 2025-2038.

Batt, C.M., 1997. The British archaeomagnetic calibration curve: an objective treatment. Archaeometry 39, 153-168.

Benson, L., Liddicoat, J., Smoot, J., Sarna-Wojcicki, A., Negrini, R., Lund, S., 2003. Age of the Mono Lake excursion and associated tephra. Quaternary Sci. Rev. 22, 135-140.

Boggs Jr., S., Wang, W.C., Lewis, F.S., Chen, J.-C., 1979. Sediment properties and water characteristics of the Taiwan shelf and slope. Acta Oceanogr. Taiwanica 10, 10-49.

Bond, G., Showers, W., Cheseby, M., Lotti, R., Almasi, P., deMenocal, P., Priore, P., Cullen, H., Hajdas, I., Bonani, G., 1997. A pervasive millennial-scale cycle in North Atlantic Holocene and glacial climates. Science 278, 1257-1266.

Bond, G., Kromer, B., Beer, J., Muscheler, R., Evans, M.N., Showers, W., Hoffmann, S., Lotti-Bond, R., Hajdas, I., Bonani, G., 2001. Persistent solar influence on north Atlantic climate during the Holocene. Science 294, 2130-2136.

Brachfeld, S., Domack, E., Kissel, C., Laj, C., Leventer, A., Ishman, S., Gilbert, R., Camerlenghi, A., Eglinton, L.B., 2003. Holocene history of the Larsen-A Ice Shelf constrained by geomagnetic paleointensity dating. Geology 31, 749-752.

Brachfeld, S., Banerjee, S.K., 2000. A new high-resolution geomagnetic paleointensity record for the North American Holocene: a comparison of sedimentary and absolute intensity data. J. Geophys. Res. 105, 821-834.

Cang, S., Shackleton, N.J., Qin, Y., Yan, J., 1988. The discovery and significance of Globigerinoides ruber (pink-pigmented) in Okinawa Trough. Mar. Geol. Quat. Geol. 8, 24-29.

Carcaillet, J.T., Bourles, D.L., and Thouveny, N., 2004a. Geomagnetic dipole moment and $\mathrm{Be}-10$ production rate intercalibration from authigenic Be-10/(9) Be for the last 1.3 Ma, Geochem. Geophys. Geosys., 5: Art. No. Q05006.

Carcaillet, J., Bourles, D.L., Thouveny, N., Arnold, M., 2004b. A high resolution authigenic $\mathrm{Be}-10 / \mathrm{Be}-9$ record of geomagnetic moment variations over the last $300 \mathrm{ka}$ from sedimentary cores of the Portuguese margin. Earth Planet. Sci. Lett. 219, 397-412.

Channell, J.E.T., Mazaud, A., Sullivan, P., Turner, S., Raymo, M.E., 2002. Geomagnetic excursions and paleointensities in the Matuyama Chron at Ocean Drilling Program Sites 983 and 984 (Iceland Basin). J. Geophy. Res., 107 (B6): Art. No. 2114.

Channell, J.E.T., Raymo, M.E., 2003. Paleomagnetic record at ODP Site 980 (Feni Drift, Rockall) for the past 1.2 Myrs. Geochem. Geophys. Geosys., 4: Art. No. 1033.

Channell, J.E.T., Stoner, J.S., Hodell, D.A., Charles, C.D., 2000. Geomagnetic paleointensity for the last $100 \mathrm{kyr}$ from the sub-antarctic South Atlantic: a tool for inter-hemispheric correlation. Earth Planet. Sci. Lett. 175, 145-160.

Christl, M., Strobl, C., Mangini, A., 2003. Beryllium-10 in deep-sea sediments: a tracer for the Earth's magnetic field intensity during the last 200,000 years. Quat. Sci. Rev. 22, 725-739. 
Chung, Y., Chang, W.-C., 1995. Pb-210 fluxes and sedimentation rates on the lower continental slope between Taiwan and the south Okinawa Trough. Cont. Shelf Res. 15, 149-164.

Day, R., Fuller, M., Schmidt, V.A., 1977. Hysteresis properties of titanomagnetites: grain-size and compositional dependence. Phys. Earth Planet. Int. 13, 260-267.

deMenocal, P.B., Ortiz, J., Guilderson, T., Sarnthein, M., 2000. Coherent high- and low-latitude climate variability during the Holocene Warm Period. Science 288, 2198-2202.

deMenocal, P.B., 2001. Cultural responses to climate change during the late Holocene. Science 292, 667-673.

Dunlop, D., 1986. Hysteresis properties of magnetite and their dependence on particle size: A test of pseudo-single-comain remanence models. J. Geophys. Res. 91, 9569-9584.

Eighmy, J.L., Sternberg, R.S. (Eds.), 1990. Archaeomagnetic Dating. The University of Arizona Press, Tucson, p. 446.

Frank, M., 2000. Comparison of cosmogenic radionuclide production and geomagnetic field intensity over the last 200000 years. Phil. Trans. Roy. Soc. London, Ser. A 358, 1089-1107.

Frank, U., Schwab, M.J., Negendank, J.F., 2003. Results of rock magnetic investigations on lacustrine sediments from Birkat Ram, Golan Heights (Israel). J. Geophys. Res. 108, 2379, doi:10.1029/2002JB0002049.

Genevey, A., Gallet, Y., Margueron, J.-C., 2003. Eight thousand years of geomagnetic field intensity variations in the eastern Mediterranean. J. Geophys. Res. 108, 2228, doi:10.1029/2001JB001612.

Guyodo, Y., Acton, G.D., Brachfeld, S., Channell, J.E.T., 2001. A sedimentary paleomagnetic record of the Matuyama chron from the Western Antarctic margin (ODP Site 1101). Earth Planet. Sci. Lett. 191, 61-74.

Guyodo, Y., Valet, J.P., 1996. Relative variations in geomagnetic intensity from sedimentary records: The past 200,000 years. Earth Planet. Sci. Lett. 143, 23-36.

Guyodo, Y., Valet, J.P., 1999. Global changes in intensity of the Earth's magnetic field during the past $800 \mathrm{kyr}$. Nature 399, 249-252.

Hagelberg, T., Shackleton, N.J., Pisias, N., and Shipboard Scientific Party, 1992. Development of composite depth sections for Sites 844 through 854. In: Mayer, L., Pisias, N., Janecek, T., et al. Init. Repts. Ocean Drilling Program, 138 (Pt. 1): 79-85.

Hedley, I.G., 2001. New directions in archaeomagnetism. J. Radioanal. Nuclear Chem. 247, 663-672.

Hideshima, S., Matsumoto, E., Abe, O., Kitagaawa, H., 2001. Northwest Pacific marine reservoir correction estimated from annually banded coral from Ishigaki Island. Southern Japan Radiocarbon $43,473-476$

Horng, C.S., Roberts, A.P., Liang, W.T., 2003. A 2.14-Myr astronomically tuned record of relative geomagnetic paleointensity from the western Philippine Sea. J. Geophys. Res., 108 (B1): Art. No. 2059.

Hrouda, F., 1994. A technique for the measurement of thermal changes of magnetic susceptibility of weakly magnetic rocks by the CS-2 apparatus and KLY-2 Kappabridge. Geophys. J. Int. 118, 604-612.

Katari, K., Tauxe, L., King, J., 2000. A reassessment of postdepositional remanent magnetism: preliminary experiments with natural sediments. Earth Planet. Sci. Lett. 183, 147-160.

King, J.W., Banerjee, S.K., Marvin, J., 1983. A new rock-magnetic approach to selecting sediments for geomagnetic paleointensity studies: application to paleointensity for the last 4000 years. J. Geophys. Res. 88, 5911-5921.

Kirschvink, J.L., 1980. The least-squares line and plane and the analysis of paleomagnetic data. Geophys. J. Roy. Astronom. Soc. 62, 699-718.
Kukla, G.J., 2000. Paleoclimate - the last interglacial. Science 287, 987-988.

Laj, C., Kissel, C., Mazaud, A., Channell, J.E.T., Beer, J., 2000. North Atlantic palaeointensity stack since $75 \mathrm{ka}$ (NAPIS-75) and the duration of the Laschamp event. Phil. Trans. Roy. Soc. London, Ser. A 358, 1009-1025.

Laj, C., Kissel, C., Beer, J., 2004. High resolution global paleointensity stack since 75 kyrs (GLOPIS-75) calibrated to absolute values. In: Channell, J.E.T., Kent, D.V., Lowrie, W., Meert, J.G. (Eds.), Timescales of the Paleomagnetic Field, AGU Geophysical Monograph, 145.

Laj, C., Vigliotti, L., Kissel, C., Turon, J., Duprat, J., 2003. Holocene geomagnetic paleointensity records from Atlantic Ocean and Mediterranean Sea sediments. Eos Trans. AGU, 84 (46), Fall Meet. Suppl., Abstract GP22B-05.

Levi, S., Banerjee, S.K., 1976. On the possibility of obtaining relative paleointensities from lake sediments. Earth. Planet. Sci. Lett. 29, 219-226.

Lin, F.-T., Chen, J.-C., 1983. Textural and mineralogical studies of sediments from the southern Okinawa Trough. Acta Oceanogr. Taiwanica $14,26-41$.

McElhinny, M.W., Senanayake, W.E., 1982. Variations in the geomagnetic dipole 1, the past 50000 years. J. Geomag. Geoelectr. 140, $39-51$.

Meynadier, L., Valet, J.P., Weeks, R., Shackleton, N.J., Lee Hagee, V., 1992. Relative geomagnetic intensity of the field during the last 140 ka. Earth Planet. Sci. Lett. 114, 39-57.

Moran, K., 1997. Elastic property corrections applied to Leg 154 sediment, Ceara Rise. In: Shackleton, N.J., Curry, W.B., Richter, C., Bralower, T.J. (Eds.), Proc. ODP, Sci. Results. College Station, TX (Ocean Drilling Program), 154, pp. 151-156.

Nunez, J.I., Osete, M.L., Bernal, D., Tarling, D.H., 2000. A first secular variation curve for Spain from archaeomagnetic data. Geol. Carpath. 51, 183-184.

Ohno, M., Hamano, Y., 1993. Global analysis of the geomagneticfield: time variation of the dipole moment and the geomagnetic pole in the Holocene. J. Geomagn. Geoelectr. 45, 14551466.

Paillard, D., 1996. Macintosh program performs time-series analysis. EOS 77, 379.

Salisbury, M.H., Shinohara, M., Richter, C., et al., 2002. Proc. ODP, Init. Repts., 195, 1-46 [CD-ROM]. Available from: Ocean Drilling Program, Texas A\&M University, College Station TX 77845-9547, USA.

Schnepp, E., Pucher, R., 2000. The German archaeomagnetic secular variation curve. Geol. Carpath. 51, 184-184.

Snowball, I., Sandgren, P., 2002. Geomagnetic field variations in northern Sweden during the Holocene quantified from varved lake sediments and their implications for cosmogenic nuclide production rates. Holocene 12, 517-530.

Sprowl, D.R., Banerjee, S.K., 1989. The Holocene paleosecular variation record from Elk Lake, Minnesota. J. Geophys. Res. 94, 9369-9388.

Stoner, J.S., Channell, J.E.T., Hillaire-Marcel, C., Kissel, C., 2000. Geomagnetic paleointensity and environmental record from Labrador Sea core MD95-2023: Global marine and ice core chronostratigraphy for the last $110 \mathrm{kyr}$. Earth Planet. Sci. Lett. 183, 161-177.

Stoner, J.S., Channell, J.E.T., Hodell. D,A, Charles, C.D., 2003. A similar to $580 \mathrm{kyr}$ paleomagnetic record from the sub-Antarctic South Atlantic (Ocean Drilling Program Site 1089). J. Geophys. Res., 108: Art. No. 2244. 
Stoner, J.S., Laj, C., Channell, J.E.T., Kissel, C., 2002. South Atlantic and North Atlantic geomagnetic paleointensity stacks (0-80 ka): implications for inter-hemispheric correlation. Quat. Sci. Rev. 21, 1141-1151.

St-Onge, G., Stoner, J.S., Hillaire-Marcel, C., 2003. Holocene paleomagnetic records from the St. Lawrence Estuary, eastern Canada: centennial- to millennial-scale geomagnetic modulation of cosmogenic isotopes. Earth Planet. Sci. Lett. 209, 113-130.

Tauxe, 1993. Sedimentary records of relative paleointenstiy of the geomagnetic field: theory and practice. Rev. Geophys. 31, 319-354.

Tauxe, L., LaBrecque, J.L., Dodson, R., Fuller, M., 1983. U-channels a new technique for paleomagnetic analysis of hydraulic piston cores. EOS Trans. AGU 64, 219.

Thompson, P.R., Bé, A.W.H., Duplessy, J.-C., Shackleton, N.J., 1979. Disappearance of pink-pigmented Globigerinoides ruber at $120,000 \mathrm{yr}$ BP in the Indian and Pacific Oceans. Nature 280, $554-558$.

Thouveny, N., Carcaillet, J., Moreno, E., Leduc, G., Nerini, D., 2004. Geomagnetic moment variation and paleomagnetic excursions since 400 kyr BP: a stacked record from sedimentary sequences of the Portuguese margin. Earth Planet. Sci. Lett. 219, 377396.

Tric, E., Valet, J.P., Tucholka, P., Paterne, M., Labeyrie, L., Guichard, F., Tauxe, L., Fortugne, M., 1992. Paleointensity of the geomagnetic field during the last 80,000 years. J. Geophys. Res. 97, 9337-9351.

Valet, J.P., Meynadier, L., 1998. A comparison of different techniques for relative paleointensity. Geophys. Res. Lett. 25, 89-92.

Valet, J.P., 2003. Time variations in geomagnetic intensity. Rev. Geophys. 41, 1004, doi:10.1029/2001RG000104.
Venuti, A., Richter, C., Verosub, K.L., 2005. Data Report: Paleomagnetic and environmental magnetic properties of sediments from Site 1202 (Kuroshio Current). In Salisbury, M., Shinohara, M., Richter, C. (Eds.). Proc. ODP, Sci. Results, 195 [Online]. Available from World Wide Web: http://www-odp.tamu.edu/ publications/195_SR/111/111.htm.

Verosub, K.L., Mehringer Jr., P.J., Waterstraat, P., 1986. Holocene secular variation in western North America: paleomagnetic record from Fish Lake, Harney County. Oregon. J. Geophys. Res. 91, 3609-3623.

Weeks, R., Laj, C., Endignoux, L., Fuller, M., Roberts, A., Manganne, R., Blanchard, E., Goree, W., 1993. Improvements in long-core measurement techniques: applications in palaeomagnetism and palaeoceanography: Geophys. J. Int. 114, 651-662.

Wefer, G., Berger, W.H., Richter, C., et al., 1998. Proc. ODP, Init. Repts., 175: College Station, TX (Ocean Drilling Program).

Wei, K.Y., Mii, H.-S., Huang, C.-Y., 2005. Age model and oxygen isotope stratigraphy of Site 1202 in Southern Okinawa Trough, northwest Pacific. Terrestrial, Atmospheric, and Oceanic Sciences $16(1), 1-17$.

Yamazaki, T., 2002. Long-term secular variation in geomagnetic field inclination during Brunhes Chron recorded in sediment cores from Ontong-Java Plateau. Phys. Earth Planet. Int. 133, 57-72.

Yang, S., Odah, H., Shaw, J., 2000. Variations in the geomagnetic dipole moment over the last 12000 years. Geophys. J. Int. 140, $158-162$.

Zhao, M., Huang, C.Y., Wei, K.Y., 2005. A 28,000 year UK37 sea surface temperature record of ODP Site 1202B, Southern Okinawa Trough. Terrestrial, Atmospheric and Oceanic Sciences 16 (1), 45-56. 